7. Reprod. Fert. (1969) 18, 59-66

\title{
A CLINICAL TRIAL OF A NEW TOTALLY SYNTHETIC LOW DOSE PROGESTAGEN
}

\author{
G. L. FOSS \\ Male Subfertility and Endocrine Clinics, Bristol
}

(Received 7th February 1968)

\begin{abstract}
Summary. The new totally synthetic progestational steroid norgestrel has been subjected to a clinical trial in gynaecological and endocrine cases and for oral contraception, and its toxicity and side-effects have been investigated. The effect of norgestrel alone and in combination with ethinyl oestradiol in various dosage/time schedules on the endometrium has been studied. The previous reports of its effectiveness in low dosage combinations with oestrogen with absence of significant side-effects or toxicity have been confirmed. These findings, together with its very high potency, make it an important addition to progestational therapy in gynaecological practice and for oral contraception.
\end{abstract}

\section{INTRODUGTION}

Recently a very potent progestagen Wy-3707, norgestrel, was derived by a method of total synthesis from bench chemicals (Smith and his colleagues, 1963). The compound (DL-13 $\beta$-ethyl-17 $\alpha$-ethynyl-17 $\beta$-hydroxygon-4-en-3-one) resembles norethisterone in certain structural characteristics, but possesses a unique angular ethyl group in position 13 of the steroid nucleus. Norgestrel is a racemate, the $D$ form being active biologically, whereas the $L$ form is inert (Edgren, Smith, Hughes, Smith \& Greenspan, 1963).

The formula and its comparison to norethisterone are as follows:<smiles>C#CC1(O)CCC2C3CCC4=CC(=O)CCC4C3CCC21CCC</smiles>

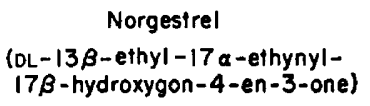<smiles>C#CC1(O)CCC2C3CCC4=CC(=O)CCC4C3CCC21CC</smiles> 
Much animal experimental work on this progestagen has been carried out, and this is well summarized by Edgren, Peterson \& Jones (1966).

When compared with other oral progestagens in the human, by the Greenblatt/Swyer postponement of menstruation assay, norgestrel appeared over ten times more potent than any other compound so far tested (Mears, 1965). Reports on its use in gynaecology (Greenblatt \& Junck, 1966), as a contraceptive with added oestrogen (Roland, 1966; O'Roark, Lock, Smith Foushee \& Burt, 1966; McBridge, 1967) and for the treatment of threatened abortion (Swyer \& Little, 1965a, b) have made claims for its efficiency and low incidence of side effects.

\section{METHODS AND MATERIALS}

For 3 years this progestagen has been investigated in Bristol to determine the effective doses for induction of cyclical withdrawal bleeding, the control of irregular or heavy bleeding and the suppression of menstruation. It has also been given to patients as an oral contraceptive. Studies have been made on its effect on the endometrium in various combinations of dosage, alone or in combination with ethinyl oestradiol (EO). Gareful record was made of any sideeffects and a group of patients was investigated by serial liver function tests to determine possible toxic effects of various doses. Experience has been limited to the study of 125 patients for over 1100 treated cycles. Detailed records were made when patients were seen at 1- or 2-monthly intervals.

Sections of endometrium were obtained after various dosage regimens and were obtained either by biopsy or at hysterectomy. The endometrium was fixed in Bouin's solution, and sections were stained with haematoxylin and eosin. Liver function tests were carried out before and at intervals during treatment. These included serum bilirubin, alkaline phosphatase, serum proteins and electrophoresis, and either serum glutamic oxalo-acetic transaminase (SGOT), or serum glutamic pyruvic transaminase (SGPT). Blood urea and blood counts and urine analyses were also made. Blood samples were collected at the end of a course of treatment or cycle.

Cervical smears were done in married women after several months' treatment.

The doses of norgestrel used at the start of the trial were based on those used by Greenblatt \& Junck (1966), but it soon became apparent that they were too high, and, as experience accumulated with norgestrel (and particularly from previous experience with norethisterone; Foss, 1960), adjustments were made.

\section{RESULTS}

\section{Induction of regular cyclical bleeding}

Nine patients aged 17 to 20 years with primary amenorrhoea and ten patients, aged 20 to 43 years, with long-standing secondary amenorrhoea have been treated for over 300 cycles. Satisfactory induction of withdrawal bleeding with good cycle control was achieved with a combination of norgestrel $0.5 \mathrm{mg}$ and EO $0.05 \mathrm{mg}$ given daily for 21 days each month. The onset of bleeding occurred within 6 days of finishing a course of treatment. 


\section{Menometrorrhagia}

The control of heavy, irregular or regular bleeding with norgestrel alone was unsatisfactory, as its effect was not immediate and the dose required, 4 to $8 \mathrm{mg}$, was too near the limit of tolerance. When EO was added, its action was accentuated and flooding was stopped within $48 \mathrm{hr}$ on norgestrel $0.5 \mathrm{mg}$ and EO $0.05 \mathrm{mg}$ four times per day. Menstruation was then suppressed for long intervals quite readily. This was a useful therapeutic measure for nine patients until the day of hysterectomy and the patient with the longest suppression was on the waiting list for 273 days.

If hysterectomy was not indicated, patients were then given cyclical treatment for 21 days each month with norgestrel 0.5 to $1.5 \mathrm{mg}$ and EO 0.05 to $0.1 \mathrm{mg}$ daily. In this manner bleeding was normal or scanty and regular in sixty-three out of seventy-five treated cycles.

TABLE 1

SUPPRESSION OF MENSTRUATION

\begin{tabular}{cc|l}
\hline $\begin{array}{c}\text { Continuous daily dose } \\
\begin{array}{c}\text { Norgestrel }+ \text { Ethinyl oestradiol } \\
(\mathrm{mg})\end{array}\end{array}$ & \multicolumn{1}{|c}{ Days of suppression } \\
\hline 3.5 & 0.05 & \multicolumn{1}{|c}{65} \\
$2 \cdot 0$ & $0 \cdot 2$ & 29,235 \\
$2 \cdot 0$ & $0 \cdot 1$ & $48,49,56,63$ \\
$2 \cdot 0$ & 0.05 & 63,108 \\
$1 \cdot 0$ & $0 \cdot 1$ & $56,68,112,115,162,166,273,364$ \\
$1 \cdot 0$ & 0.05 & $77,93,106$ \\
0.5 & 0.05 & $51,53,54,67,92,216,224$ \\
\hline
\end{tabular}

\section{Oral contraception}

A small pilot trial with fifty-eight patients was carried out. Four of these were newly married and the rest had had one to six children. Cyclical treatment was given for 21 days each month. A combination of norgestrel $1.0 \mathrm{mg}$ plus EO $0.05 \mathrm{mg}$ was first given for 210 cycles and then the dose of norgestrel was reduced to $0.5 \mathrm{mg}$ together with $\mathrm{EO} 0.05 \mathrm{mg}$ for 277 cycles. None of these patients became pregnant. In this small series of 487 cycles, break-through bleeding or spotting for 1 or more days occurred in $3.2 \%$ of cycles. One patient on the $1.0-\mathrm{mg}$ dose of norgestrel and one patient on $0.5 \mathrm{mg}$ had amenorrhoea, in each case for 2 months.

\section{Endometrial studies}

These were made in sixteen patients on nineteen occasions (Table 2).

Side-effects

An assessment of side-effects was made when norgestrel had been given to eighty-eight patients, with ages ranging from 17 to 51 years, for 764 cyclemonths (Table 3 ), and were analysed separately for forty-seven patients who had, at that time, been given this compound for oral contraception. The sideeffects were minimal, except when the larger doses of norgestrel were used alone 


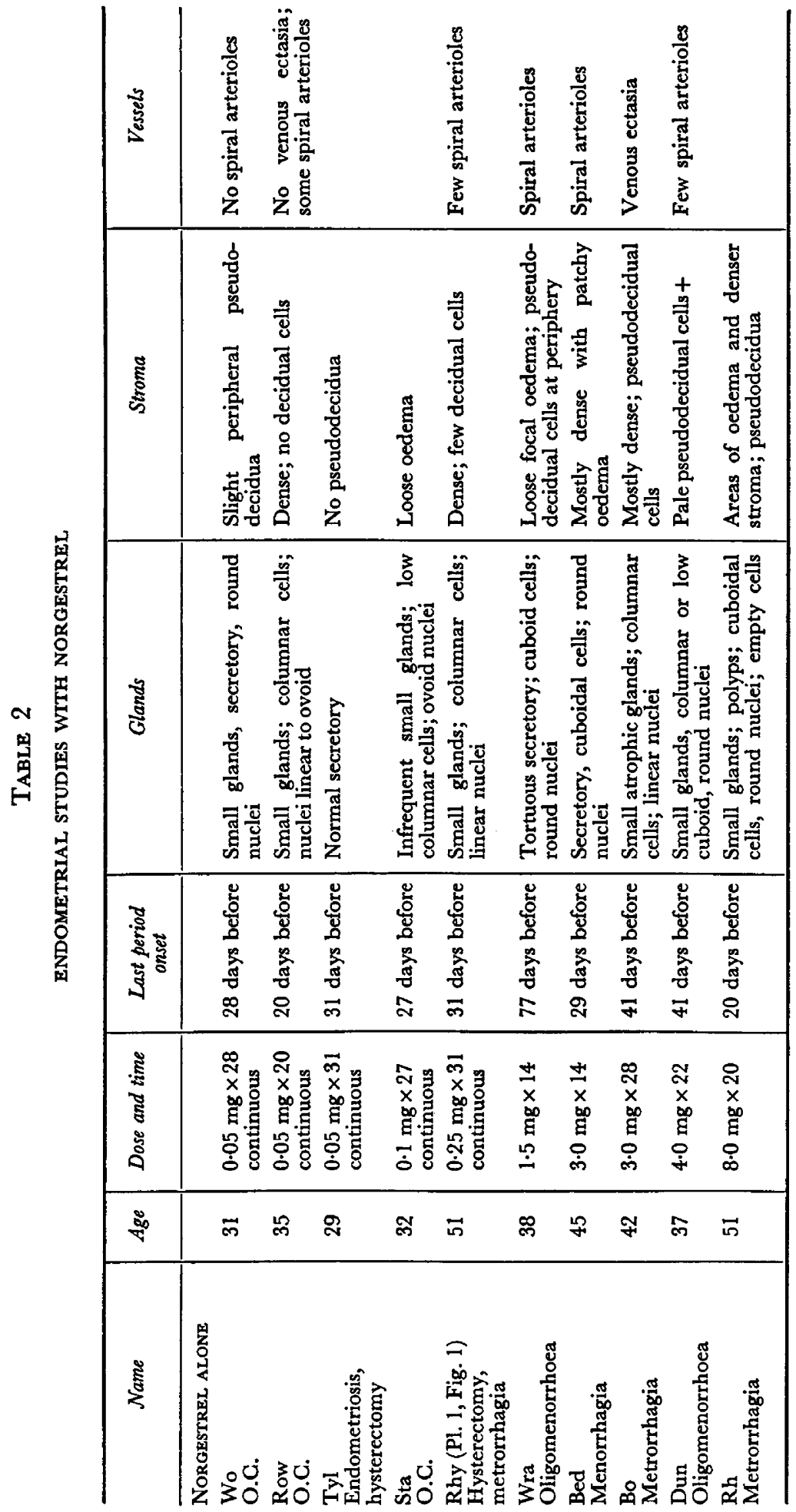


Clinical trial of a low dose progestagen

\begin{tabular}{|c|c|c|c|c|c|c|c|c|}
\hline 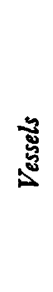 & & & 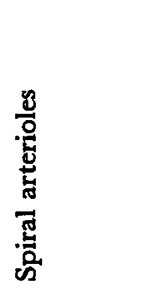 & 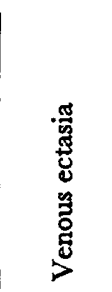 & & 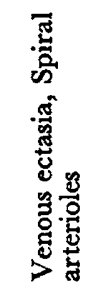 & & 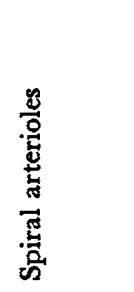 \\
\hline है & 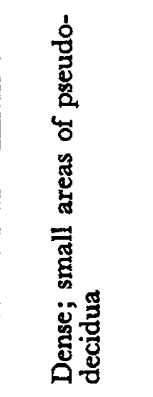 & 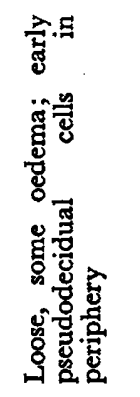 & 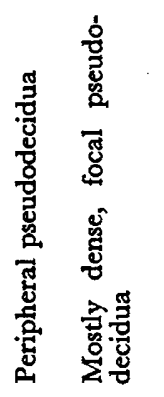 & 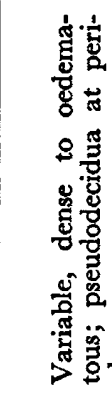 & & 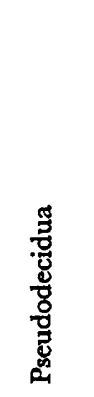 & 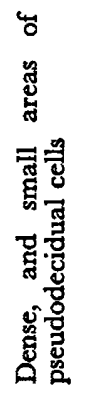 & 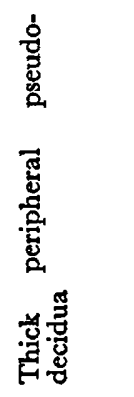 \\
\hline$\frac{\widetilde{\Xi}}{\mathbb{J}}$ & 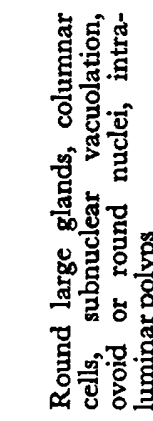 & 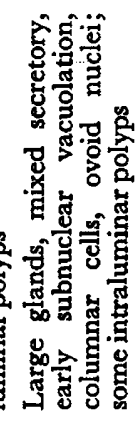 & 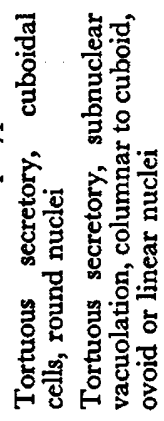 & 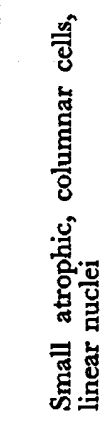 & 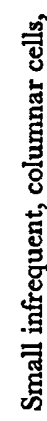 & 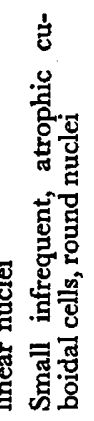 & 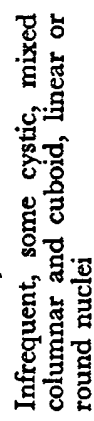 & 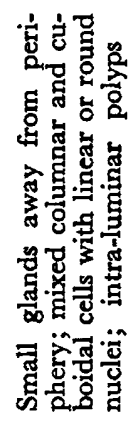 \\
\hline 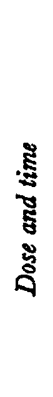 & 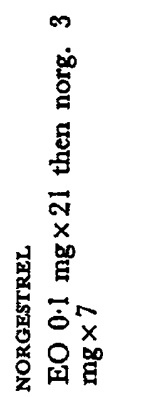 & 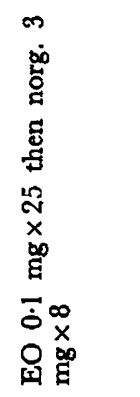 & 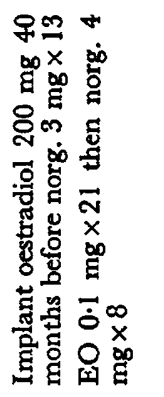 & $\begin{array}{l}\vec{a} \\
x \\
80 \\
\vdots \\
\vec{a} \\
\dot{0} \\
\dot{0} \\
\vdots \\
+ \\
0 \\
a \\
0 \\
0 \\
0 \\
0 \\
0\end{array}$ & 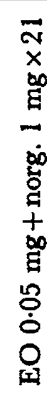 & 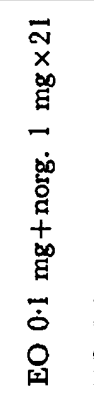 & 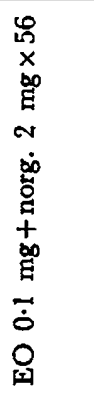 & 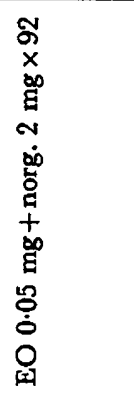 \\
\hline षै & 查 & $\hat{m}$ & ஜ্ల & $\lesssim$ & ले & 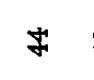 & \& & 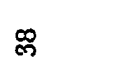 \\
\hline 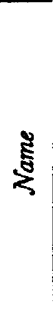 & 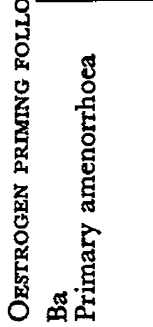 & 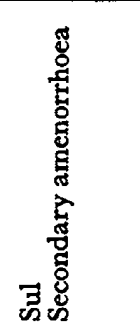 & 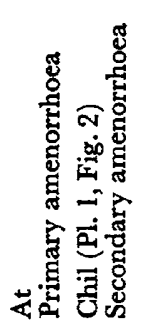 & 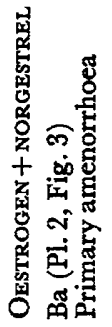 & & 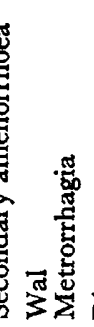 & 莺 & 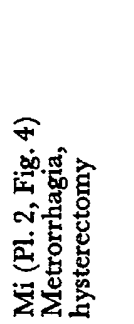 \\
\hline
\end{tabular}


for long periods. With the low dosage 0.5 to $1.0 \mathrm{mg}$ norgestrel plus EO $0.05 \mathrm{mg}$ used cyclically for oral contraception or amenorrhoea, the incidence was highest in the first treated cycles-tiredness, weakness, headache and nausea being the most common complaints.

TABLE 3

SIDE-EFFECTS

\begin{tabular}{l|c}
\hline \multicolumn{1}{c|}{ Side-effect } & Percentage* $^{*}$ \\
\hline Nausea & 8.4 \\
Tiredness & 6.2 \\
Headache & 5.2 \\
Breast tenderness & 3.6 \\
Depression or irritability & 3.2 \\
Bloated feeling & 0.7 \\
Abdominal discomfort & 0.5 \\
Vomiting & 0.4 \\
Oedema & 0.3 \\
Blurred vision & 0.1 \\
\hline
\end{tabular}

* Expressed as a percentage of 764 cycle-months.

\section{Investigation of toxicity}

Blood samples were collected from eighty-seven patients on 355 occasions. No abnormalities were found in full blood counts, blood urea estimations or serum proteins. Urine analysis completed on all these occasions was normal.

Cervical smears were examined in thirty-six married women, and all were assessed by the pathologist as Grade I or II.

Fifty-four patients had serial transaminases done. Six patients had raised SGPT in the first cycle of treatment when the control value had been normal. They reverted to normal limits thereafter in succeeding months. Four patients with no control value had a raised SGPT for the first estimation and these reverted to normal with treatment. One of these was ill at the time of examination with a salmonella infection.

In one case of menorrhagia treated by suppressing menstruation with 4 $\mathrm{mg}$ norgestrel alone for 6 weeks, there was a high level of 540 units $/ \mathrm{ml}$ at 1 month, but no control cycle was done. High levels were seen in this same patient on three other occasions, when she had been given doses of 1.5 to $3.5 \mathrm{mg}$ daily alone, in an attempt to suppress menstruation.

However, in another patient, $8 \mathrm{mg}$ daily for 14 days produced severe nausea, tiredness and a bloated feeling, necessitating withdrawal of treatment, but the SGOT was not above 23 units. A level of SGOT above 30 units (the normal upper limit) was only seen on two occasions in two out of thirty patients, one after suppression with norgestrel $2 \mathrm{mg}$ plus EO $0.05 \mathrm{mg}$ for 32 days, and the other after suppression with norgestrel $3 \mathrm{mg}$ plus EO $0.15 \mathrm{mg}$ for 28 days. These were both the first assessment at 1 month and reverted to normal limits thereafter with continued treatment. 

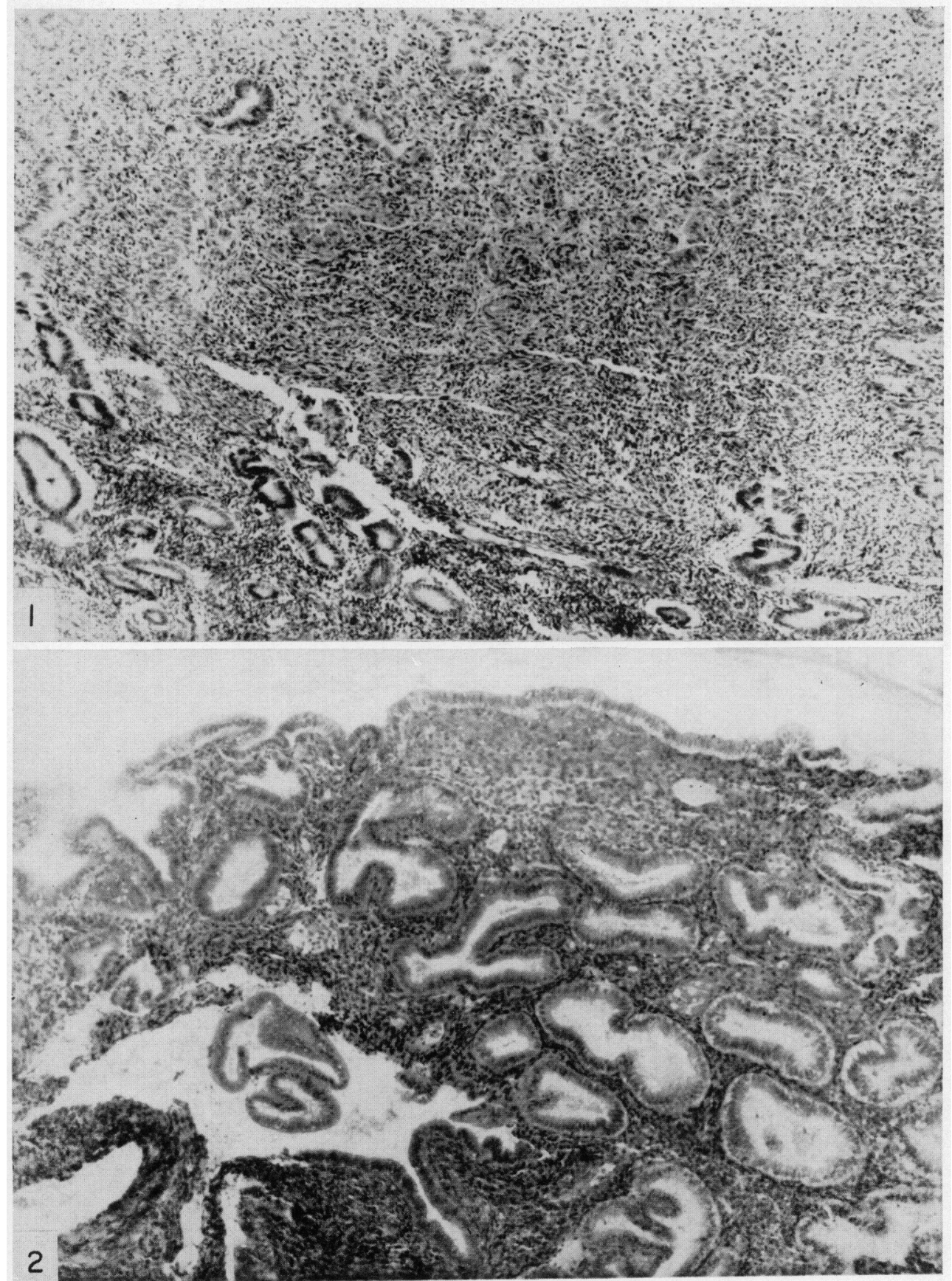

FIG. 1. Rhy. Small glands; columnar cells; linear nuclei; dense stroma; few decidual cells; few spiral arterioles (see Table 2). $\mathrm{H} \& \mathrm{E}, \times 100$.

Fig. 2. Chil. Glands secretory with subnuclear vacuolation; stroma mostly dense; focal pseudodecidual cells (sec Table 2). H \& E. $\times 100$.

(Facing p. 64) 

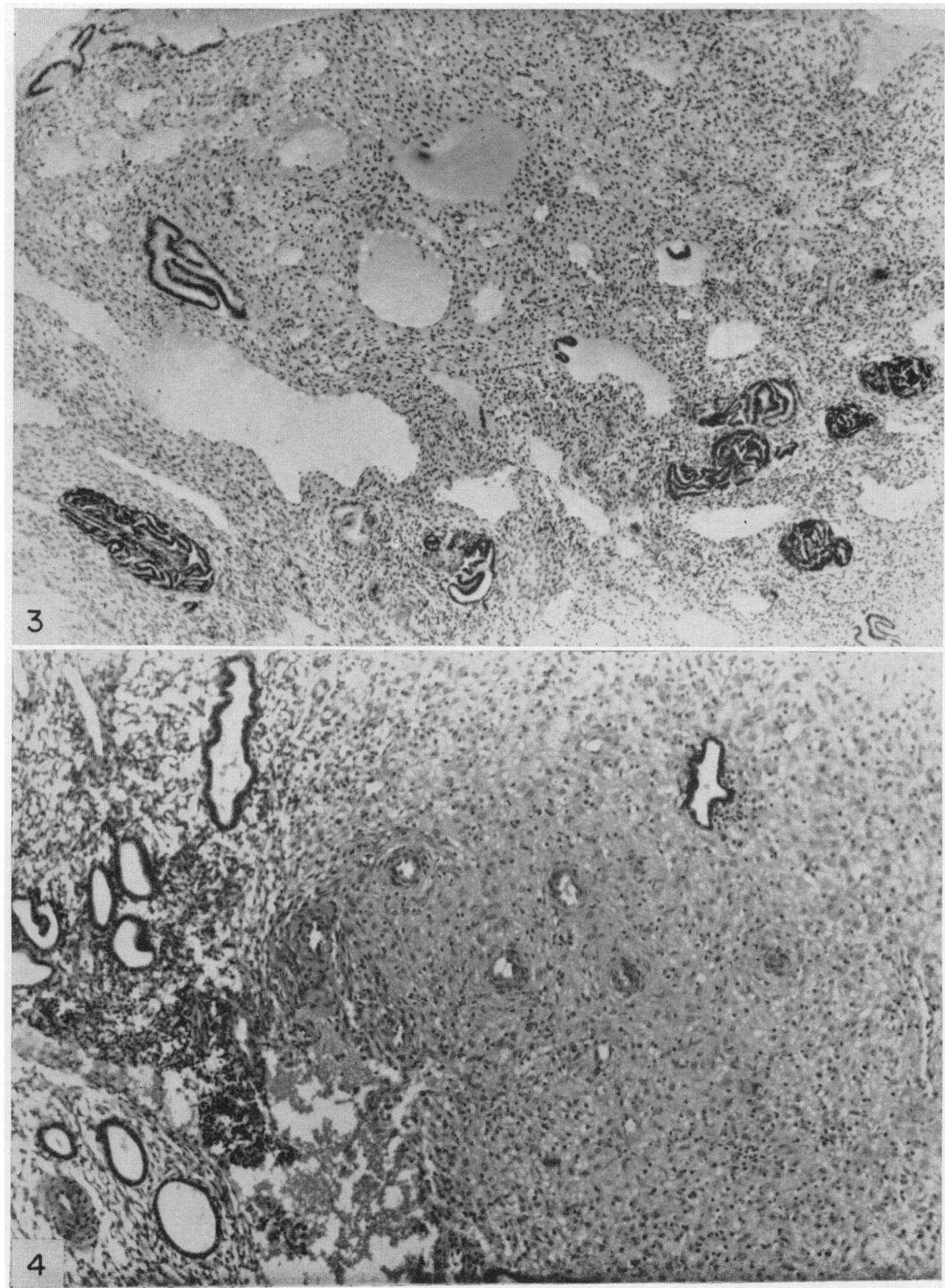

Fic. 3. Ba. Clands small and atrophic; stroma dense to ocdematous; pseudodecidual cells at periphery; venous cetasia (see Table 2). H \& E, $\times 100$.

Fis. 4. Mi. Glands small; mixed columnar and cuboid cells; thick peripheral pseudodecidua; spiral arterioles evident (sce Table 2). H \& E, $\times 100$. 
Alkaline phosphatase was only above the normal range ( 15 units $/ \mathrm{ml}$ ) on three occasions, at which time the SGOT figures were normal.

Serum bilirubin was above normal in two patients, on one occasion each. One patient had obstructive jaundice due to gallstones which were removed.

\section{DISCUSSION}

Greenblatt \& Junck (1966) reported on a series of 288 assorted gynaecological patients who received 1000 courses of medication with norgestrel 1.25 to 30 mg daily. They showed that dysfunctional uterine bleeding could be controlled by norgestrel alone, in a dose of 2.5 to $30 \mathrm{mg}$, within $48 \mathrm{hr}$ in $92 \%$ of cases. In the present series, $4 \mathrm{mg}$ sometimes failed to stop flooding in $48 \mathrm{hr}$, whereas 8 $\mathrm{mg}$ daily produced unacceptable side-effects. Norgestrel given for 7 to 10 days (i.e. starting either from the 21 st or 18 th day of the cycle respectively) controlled menstrual loss, but some break-through bleeding occurred. When EO 0.05 to $0.1 \mathrm{mg}$ was added to norgestrel, good suppression of bleeding or control of cycles was obtained.

The combination of $0.5 \mathrm{mg}$ of norgestrel with EO $0.05 \mathrm{mg}$ given four times daily is a valuable method of treatment for controlling and suppressing heavy bleeding even in the presence of large fibroids, and amenorrhoea can be continued until a patient is admitted for elective hysterectomy, allowing haemoglobin levels to be made up so that transfusion is not necessary, after admission, in preparation for operation. The gynaecologists assured me that this suppressive treatment did not make the operation technically more difficult. Such measures can also be used temporarily to postpone menstruation for a honeymoon, or other important social or sporting occasion.

As norgestrel has little intrinsic oestrogenic activity its use in practice in low dosage is undoubtedly enhanced when combined with ethinyl oestradiol. The combination of norgestrel $0.5 \mathrm{mg}$ with EO $0.05 \mathrm{mg}$ would appear to be satisfactory for the induction of cyclical withdrawal bleeding in cases of primary or secondary amenorrhoea and as an oral contraceptive.

Richards (1967) has reported the results of the combined trials in the British Family Planning Clinics and in America. There have been no pregnancies in this moderately large series of 4637 patients during 27,055 cycles. Their results of success rate and side-effects are similar to my findings in a very much smaller series.

The endometrial changes were similar to those described by Ober (1966) and Roland, Clyman, Decker \& Ober (1966).

Investigation of serial liver function tests, blood counts, blood urea and urine analyses on 355 occasions did not show any evidence of toxicity, except in one case given large doses, in which definite side-effects were associated with elevation of SGPT.

Norgestrel is an effective progestational steroid, when in combination with added EO, at a much smaller dosage than any other progestagen. Side-effects, break-through bleedings and amenorrhoea are of minimal concern. In view of its high potency and its synthetic production, it offers advantages over other preparations in current use. 


\section{ACKNOWLEDGMENTS}

My thanks are due to Mrs Marjorie Bennett, Mr H. L. Shepherd, Mr S. D. Loxton and $\mathrm{Mr}$ Howard John for allowing me to treat their patients, to $\mathrm{Dr}$ A. L. Taylor, Dr J. Cornes, Dr R. J. Sandry, Dr Norman Brown and Dr F. Lewis for pathological investigations, and to the Department of Pathology, University of Bristol, for the microphotographs.

Generous supplies of norgestrel were provided by Dr David Richards of John Wyeth \& Brother Limited.

\section{REFERENCES}

Edgren, R. A., Peterson, D. L. \& Jones, R. G. (1966) Some progestational and antifertility effects of Norgestrel. Int. F. Fert. 11, 389.

Edgren, R. A., Smith, H., Hughes, G. A., Smith, L. L. \& Greenspan, G. (1963) Biological effects of racemic and resolved 13 -ethyl-4-gonen-3-ones. Steroids, 2, 731.

Foss, G. L. (1960) Clinical experience with norethisterone and norethisterone acetate. Br. med. J. ii, 1187.

Greenblatt, R. B. \& Junck, E. G. (1966) Gynecologic uses of a new multifaceted progestogen. Clin. Pharmac. Ther. 7, 490.

MaBride, W. G. (1967) A clinical trial of a new low dose oral contraceptive compound. Aust. N.Z. Fnl Obstet. Gynaec. 7, 122.

Mrars, E. (1965) Postponement of menstruation assays. In: Handbook of Oral Contraception, p. 18. Churchill, London.

Orer, W. B. (1966) Synthetic progestogen-oestrogen preparations and endometrial morphology. $\mathcal{F}$. clin. Path. 19, 138.

O'Roark, H. C., Lock, F. R., Smith Foushee, J. H. \& Burt, R. L. (1966) Clinical study of Wy 3707 and ethinyl estradiol as an oral contraceptive. Int. F. Fert. 11, 405.

Richards, D. J. (1967) Contraceptive data on norgestrel (Wy 3707) $0.5 \mathrm{mg}$ together with ethinyl oestradiol 0.05 mg. Acta endocr., Copenh. 56, Suppl. 119, 149.

Roland, M. (1966) Wy 3707, a totally synthesized progestogen for contraception. Int. F. Fert. 11, 401.

Roland, M., Clyman, M. J., Decker, A. \& Ober, W. B. (1966) Control of conception with a new progestational steroid. Obstet. Gynec., N.Y. 27, 222.

Sмгтн, $H$. and colleagues. (1963) Totally synthetic $( \pm)$-13-alkyl-3-hydroxy and methoxy-gona-1,3,5 (10)-trien-17-ones and related compounds. Experientia, 19, 394.

Swyer, G. I. M. \& Little, V. (1965a) Progestational agents and disturbances of pregnancy. 7. Obstet. Gynaec. Br. Commonw. 72, 1014.

SWYER, G. I. M. \& LITTLE, V. (1965b) Absence of hepatic impairment in long term oral-contraceptive users. Br. med. F. i, 1412. 